\title{
Use of Macrozoobenthic for Water Quality Monitoring in Ecotourism Area of Prafi River, Manokwari, West Papua
}

\author{
Sabarita Sinuraya ${ }^{1,2^{*}}$, Endang Arisoesilaningsih², Suharjono ${ }^{2}$, Catur Retnaningdyah ${ }^{2}$ \\ ${ }^{1}$ Department of Biology, Faculty of Mathematics and Natural Sciences, University of Papua, Manokwari, Indonesia \\ 2Department of Biology, Faculty of Mathematics and Natural Sciences, University of Brawijaya, Malang, Indonesia
}

\begin{abstract}
The aim of research is to monitor the water quality of some ecotourism sites along Prafi Rivers (Manokwari, West Papua) using macrozoobenthic biotic index, Prati's index and some chemical-physical factors of water. Research was done from July to September 2016. Sampling was performed through Purposive Random Sampling. Macrozoobenthic was collected from each sampling sites in three locations, (upstream, middle stream, downstream) using Surber net and hand net. Water quality was categorized based on Implicit Prati's Pollution index that is derived from DO, BOD, $\mathrm{pH}_{\text {, }}$ nitrate, orthophosphate, and water temperature values. Macrozoobenthic data was used to analyze the diversity index and six biotic indices. Result of the study showed that $\mathrm{DO}, \mathrm{BOD}_{5}, \mathrm{pH}$ and nitrate value in all location meet the standard quality for water based on PP. no 82, 2001 class II (fisheries, recreation, animals husbandry, and irrigation). The turbidity value in sites of upstream, middle stream and downstream Subsay and $\mathrm{SP}_{3}$ have made the standard water quality according to WHO for drinking water $(<5 \mathrm{NTU})$. Based on the Prati's index, the water quality was ranging from excellent to acceptable categories with value 0.4-1.9. The taxa richness of macrozoobenthic was 31 taxa. The Shannonwiener diversity index in all stations were more than 2, indicated that the water was not polluted. The water quality of all station showed very excellent up to moderates (based on $\mathrm{FBI}$ ), very excellent up to very bad ( $\mathrm{HBI}$ ), and excellent up to less polluted (ASPT). Percentage of Ephemeroptera, Plecoptera, and Trichoptera (\% EPT) in all station up to $50 \%$ (excellent), except in station $\mathrm{SP}_{3}$ upstream (40\%). EPT richness value in all station excellent to moderate. It can be concluded that the water quality of Subsay in upstream, middle stream, downstream and downstream of $\mathrm{SP}_{3}$ was excellent. The middle stream of $\mathrm{SP}_{3}$ and middle stream of $\mathrm{SP}_{1}$ has moderate quality, while the water quality in $\mathrm{SP}_{3}$ upstream, $\mathrm{SP}_{1}$ upstream and SPI downstream was bad.
\end{abstract}

Keywords: Ecotourism, Prafi River, water quality.

\section{INTRODUCTION}

Ecotourism is the form of tourism with sustainable environmental principles. The regulation aspect of ecotourism development in Indonesia was based on Environmental Law no. 4,1982 , in which the aims of ecotourism is promoting the wide use of natural resources [1]. Subsay River, Prafi 1 River Reservoir $\left(\mathrm{SP}_{1}\right)$ and Prafi 3 River Reservoir $\left(\mathrm{SP}_{3}\right)$ is the river and reservoir which are used as a tourism sites in Manokwari, West Papua. A far, the natural and infrastructure potentials for tourism was poorly managed by local government. It is shown by the absent of regulation on the use of natural resources and infrastructure for tourism attraction. These rivers and reservoir were used as tourism attraction by local community in West Papua, with numerous tourist activities like bathing, swimming and fishing. The water also used to support ponds and pools, in which it is

\footnotetext{
${ }^{*}$ Correspondence address:

Sabarita Sinuraya

Email : itasabarita@gmail.com

Address : University of Papua, Manokwari, 98314,

West Papua.
}

also involved in tourism industry in Manokwari. $\mathrm{SP}_{1}$ reservoir is used as tourism sites, besides that, there is an exploration of stone, gravel and sand by community from Manokwari. Problems in tourism sites often related to the tourist activity which are contributes to the environmental aspect. A lot of tourist number of tourism sites rarely controlled and examined, leading the difficulties in recreation sites management. There is also poor carryingcapacity-based management. These aspects potentially contribute to environmental degradation in tourism sites, including water and its hydrological systems [2].

Management of Subsay Rivers and reservoir as a water resources capital is important, especially in the perspective of sustainable uses. Therefore it is crucial to perform water resources quality using biological indicator and characteristic of its physical and chemical aspects. Chemical and physical examination will inform factual condition of water quality. The limitation of chemical and physical examination is, however, related to the cost. Limited budget becomes the problem for complete examination of chemical and physical aspect of water quality [3]. Biological techniques can be alternative 
methods to examine water quality, especially in the perspectives of sustainability of water environment management. Some advantages using biological control includes easy in implementation, rapid and low cost. This approach also able to provide picture of water quality because characteristics of biotic organism is fast in responding pollutant and environmental changes [4]. Biological analysis can be done properly using information of biotic community structure and indices analysis [5]. Community structure of macrozoobenthic is sensitive to environments that affect the quality of water.

The species of macrozoobenthic has different tolerant degree to environmental changes and therefore able to use in water quality assessment [6]. There are some indices available to uses complementarily with macrozoobenthic analysis to examine level of organic pollution in water environment, including $\mathrm{FBI}$ (Family Biotic Index) and $\mathrm{HBI}$ (Hilsenhoff Biotic Index) while ASPT index (Average Score Per Taxa) was used to identify level of toxic material pollution [7]. In practices, some Insect group from Ephemeroptera, Plecoptera and Trichoptera able to indicates the excellent water quality [8]. The Prati's implicit Index was used to analyze physical and chemical parameters that are used to identify level of pollution of water ecosystem based on DO, BOD, pH, Nitrate and Phosphate data $[9,10]$.

\section{RESEARCH METHOD} Study Area

Sampling sites was developed using Purposive Random Sampling [11]. Sample collection was collected in the beginning in summer in three location, namely Subsay River, $\left(\mathrm{SP}_{1}\right)$ and $\left(\mathrm{SP}_{3}\right)$ (Fig. 1). Sample was collected from three points (upstream, middle stream and downstream) with distance between points was $10 \mathrm{~m}$. There are totally 9 observed stations in this study.

\section{Macrozoobenthic Collections and Evaluation of Water Physical and Chemical Quality}

Macrozoobenthic with habitats of stone and gravels was sampled using Surber net and macrozoobenthic in riparian habitat using hand net. These samples were collected and separated from debris using plastic disk. Sample was done until at least 100 individual of macrozoobenthic in each station was collected to calculate biotic index value [7]. The sampled macrozoobenthos organism was collected in flacon bottle with $70 \%$ alcohol. The collected sample of macrozoobenthic was identified with microscopy examination. Identification was done using identification keys of macrozoobenthic $[8,12,13]$.

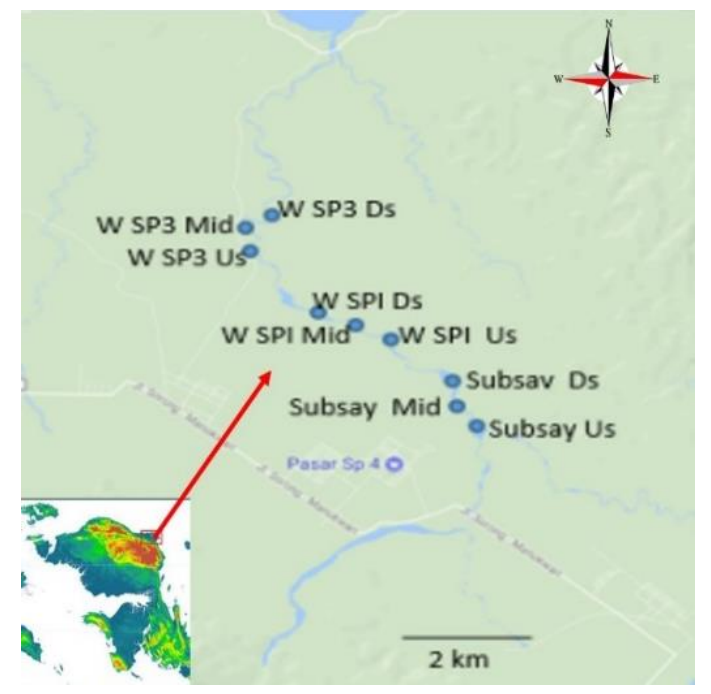

Figure 1. Sampling sites location at Prafi River, Manokwari Description:

Us = Upstream

Mid = Middle stream

Ds = Downstream

$\mathrm{SP}_{1}=$ Prafi 1 River Reservoir

$\mathrm{SP}_{3}=$ Prafi 3 River Reservoir

The examination of physical and chemical water quality in field was includes: temperature (examined using thermometers), ( $\mathrm{pH}$ examined using $\mathrm{pH}$ meter), DO (examined using DO meter and turbidity (using turbidity meter). The $\mathrm{BOD}_{5}$, nitrate and orthophosphate was analyzed in laboratory. Nitrate and orthophosphate were examined using spectrophotometer. Nitrate was analyzed using spectrophotometer with wave length $410 \mathrm{~nm}$ using Brusin methods, while orthophosphate was analyzed in wave length 690 $\mathrm{nm}$ with Stannous chloride methods [9]. Cluster and Biplot analysis based on biotic indices was done using PAST program [14].

\section{RESULT AND DISCUSSION \\ Physical and Chemical Aspects}

From nine observed stations, $\mathrm{pH}$ ranges from 7.55 to 8.46 (Fig. 2). These value has been meet water quality standard class II (water for recreation, fisheries, animal husbandry, and irrigation) in PP. No. 82, 2001 which mentioned $\mathrm{pH}$ value ranges from 6 to 9 . The highest $\mathrm{pH}$ value was 8.46 found at $\mathrm{SP}_{1}$ upstream and the lowest 7.55 found at Subsay middle stream and downstream. Increase of $\mathrm{pH}$ in $\mathrm{SP}_{1}$ and $\mathrm{SP}_{3}$ upstream caused by the increase of detergent application by community in Manokwari and its surrounding area. Detergent was used in washing. Increase of detergent in water 
ecosystem increase the water $\mathrm{pH}$; potentially it can reach 10 to 11 [4]. The $\mathrm{pH}$ of water was determined by the ability of water to release and bind hydrogen ions and level of ionized ammonium influence $\mathrm{pH}$ become low [15].

Result of the Dissolved Oxygen (DO) from nine station shows DO ranges from $7.93 \mathrm{mg} . \mathrm{L}^{-1}$ to $9.43 \mathrm{mg} \cdot \mathrm{L}^{-1}$ (Fig. 2). According to national water standardization, this value has meet the water class II. According to PP. No. 82, 2001, the DO should be more than $4 \mathrm{mg} \cdot \mathrm{L}^{-1}$ [16].The highest DO was $9.43 \mathrm{mg} . \mathrm{L}^{-1}$ found in Subsay middle stream station. This can be caused by the area along the station that has good vegetation. The lowest value (7.93 mg. $\mathrm{L}^{-1}$ ) found in $\mathrm{SP}_{1}$ upstream. This is potentially is the effect of open area and absent of vegetation. In freshwater ecosystem, dissolved oxygen was influenced by temperature, in which in $0^{\circ} \mathrm{C}$ dissolved oxygen was $14.16 \mathrm{mg} \cdot \mathrm{L}^{-1}, \mathrm{O}_{2}$ concentration decrease with the increase of water temperature [17]. Dissolved oxygen in water was caused by the contact of water surface with atmosphere and photosynthesis process
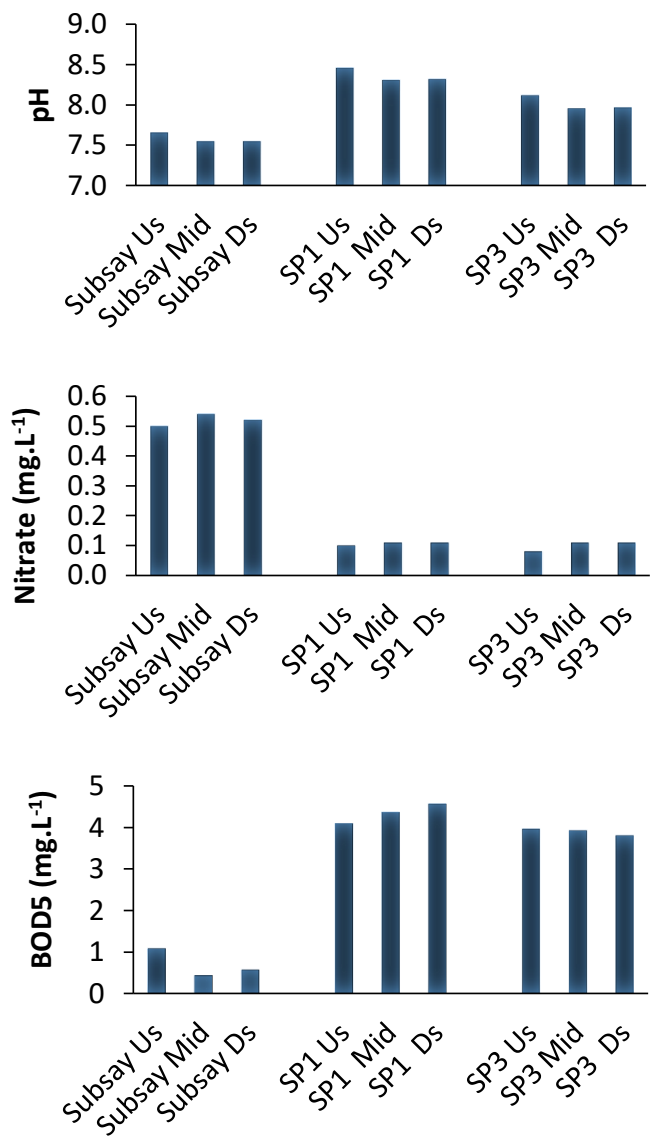

[18]. Loss of oxygen from water ecosystem occurs through oxygen release from atmospheric and respiration activity of aquatic organism [19].

The Biochemical Oxygen Demand (BOD) value of nine station was range from $0.44 \mathrm{mg} . \mathrm{L}^{-1}$ to $4.57 \mathrm{mg} . \mathrm{L}^{-1}$ (Fig. 2). These value were beyond the standard value of recommended BOD, in which governmental regulation through PP. No. 82, 2001 which state that BOD should $<3 \mathrm{mg} \cdot \mathrm{L}^{-1}$ [16]. The highest value of BOD (4.57 mg. $\left.\mathrm{L}^{-1}\right)$ was found in station $\mathrm{SP}_{1}$ downstream. It is caused by human activity (e.g. bathing, washing) that cause aerobes microorganism consume more oxygen, especially in its activity to decay an-organic compound resulted from its activity. The lowest BOD was $0.44 \mathrm{mg} . \mathrm{L}^{-1}$ found in Subsay middle stream station, represent there are human activity in the sites but in low intensity. BOD shows amount of oxygen in water that are able to consumed by aerobes microorganism in oxidize organic material in particular environment caused by human activity (e.g. bathing, washing) in river [20].
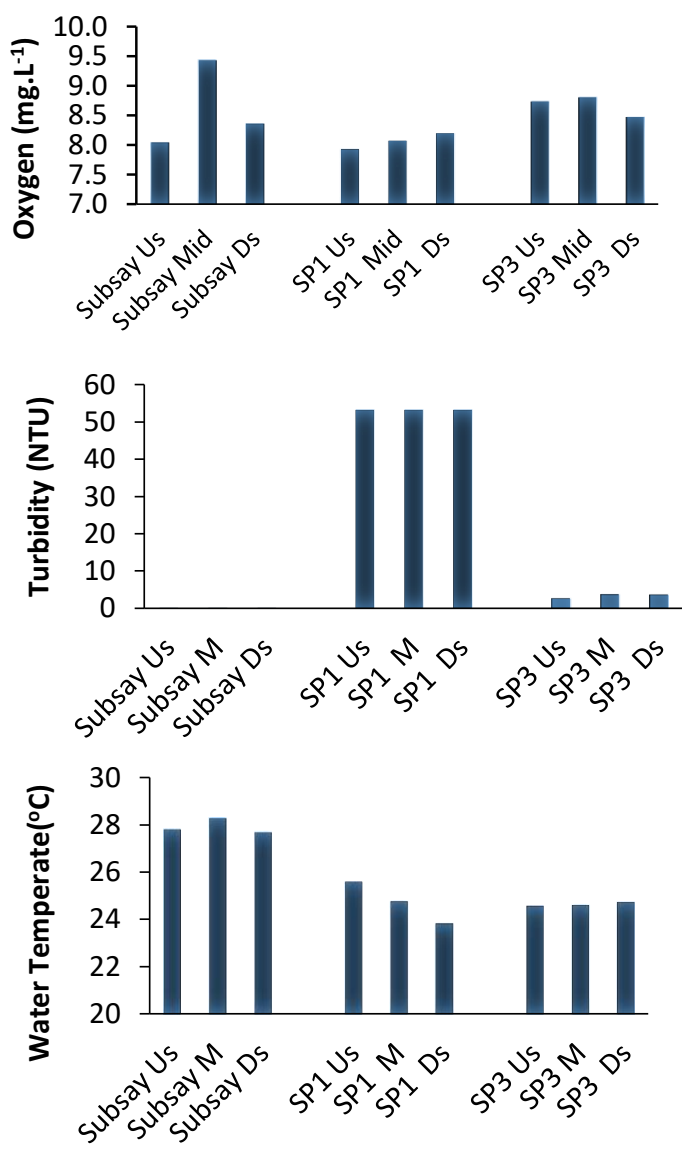

Figure 2. Mean Values of $\mathrm{pH}$, Oxygen, Nitrate, Turbidity, $\mathrm{BOD}_{5}$, and Water Temperature in Study Area Description: Us = Upstream, Mid = Middle stream, $\mathrm{Ds}=$ Downstream, $\mathrm{SP}_{1}=$ Prafi 1 River Reservoir, and $\mathrm{SP}_{3}=$ Prafi 3 River Reservoir. 
The evaluation of Nitrates from nine stations are ranging from $0.08 \mathrm{mg} . \mathrm{L}^{-1}$ to $0.54 \mathrm{mg} . \mathrm{L}^{-1}$ (Fig. 2). According to PP. No. 82, 2001, this value in ranges of water quality class $\mathrm{II}$, in which Nitrates less than $10 \mathrm{mg} \cdot \mathrm{L}^{-1}$ [16]. The highest nitrate value was $0.54 \mathrm{mg} \cdot \mathrm{L}^{-1}$ found in Subsay middle stream station and the lowest $0.08 \mathrm{mg} . \mathrm{L}^{-1}$ was found in $\mathrm{SP}_{3}$ upstream. Nitrate is the stable nitrogen that needed by organism for protein synthesis. The level and concentration of nitrates in water influence the growth of algae [21].

The turbidity evaluation of nine station ranges from 0.12 to 53.27 NTU (Fig. 2). Turbidity value in all Subsay stations and all $\mathrm{SP}_{3}$ stations meet the maximum standard of water turbidity according to WHO for drinking water (<5 NTU) [22]. Turbidity value from $\mathrm{SP}_{1}$ upstream to $\mathrm{SP}_{1}$ downstream were 53.27 NTU, 53.20 NTU and 53.23 NTU, consecutively. The high turbidity value in observed area was caused by sand exploitation and human activity (e.g. bathing). Turbidity is the important abiotic factors in water ecosystem that related to the sedimentation phenomena. Turbidity has significant impact to the organism live in water ecosystem [23].

Result of the temperature monitoring in all observed station ranges from $23.83^{\circ} \mathrm{C}$ to $28.27^{\circ} \mathrm{C}$ (Fig 2). The highest temperature was $28.27^{\circ} \mathrm{C}$ found in Subsay middle stream station. It is caused by less of plant canopy factors in this sites, lead the decrease and low sunlight that directly penetrate the water body. The lowest temperature was $23.83^{\circ} \mathrm{C}$, found in $\mathrm{SP}_{1}$ downstream station. It caused by sample time in the afternoon time [24]. Temperature pattern in aquatic ecosystem was influenced by some factors, including sunlight intensity, hot energy changes between water and its surrounding environment, altitude and tree canopy in riparian area [25].

From the calculation of Prati'S Implicit Index, it is found that $\mathrm{pH}, \mathrm{BOD} 5$, Nitrate and orthophosphate from nine observed station classified as Excellent to Acceptable [26] with value ranges from 0.42 to 1.94 (Fig 3). The high value index shows that water quality was bad. The value of Prati's index was shown in $\mathrm{SP}_{1}$ downstream station, with ranges value 1.94 and the lowest found in Subsay downstream station with value 0.42. From this data, it is shown that station $\mathrm{SP}_{1}$ is the sites with low water quality compared to the Subsay and $\mathrm{SP}_{3}$ station. This is caused by the level of DO (\%) in this station was low.

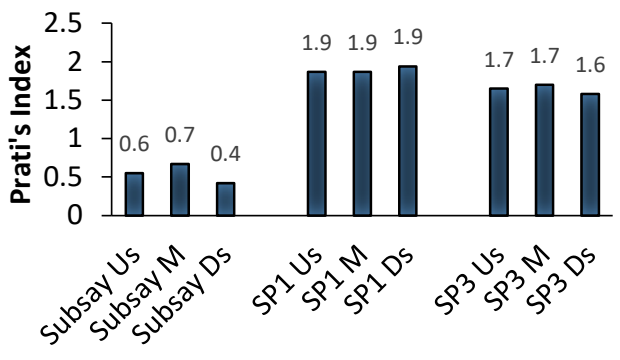

Figure 3. Water quality in all observed station based on Prati'S Implicit Index.

Description: Us = Upstream, Mid = Middle stream, Ds = Downstream, SP1 = Prafi 1 River Reservoir, and SP3 = Prafi 3 River Reservoir.

Profiles of Community Structure and MacroZoobenthicbiotic Index

There are 31 macrozoobenthic taxa found in all observed stations. It is consist of 7 Classes, including: Platyhelminthes, Coleoptera, Diptera, Ephemeroptera, Odonata, Plecoptera and Trichoptera (Table 1). There are variations of macrozoobenthic in each taxa, and not all taxa was found similarly in all stations (Fig. 4 and Table 1). The Subsay upstream station has the highest macrozoobenthic taxa (17), while the lowest found in $\mathrm{SP}_{3}$ middle stream (10). Increase of taxa number in Subsay upstream and $\mathrm{SP}_{1}$ middle stream stations was related to the increase of organic materials nutrients resulted from the natural process, including debris of organic mater from dead trees $[27,28,29]$.

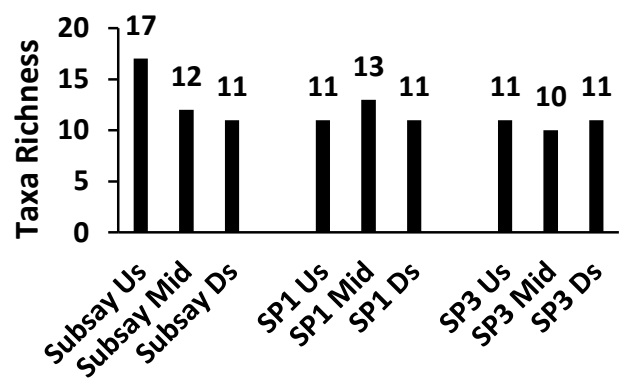

Figure 4. Variation of Spatial distribution Taxa Richness the of Macrozoobenthic in Study Site

Description: Us = Upstream, Mid = Middle stream, Ds = Downstream, SP1 = Prafi 1 River Reservoir, and SP3 $=$ Prafi 3 River Reservoir.

Decrease of taxa number in Subsay middle stream, Subsay downstream, all $\mathrm{SP}_{1}$ stations, and all $\mathrm{SP}_{3}$ stations was related to the increase content of detergent which is released to the water environment through human activity, including agricultural activity, recreation activity and daily life human activity in the observed sites. From all observed sites, sensitive 
macrozoobenthic to pollution were found. It is including Ephemeroptera, Plecoptera and Trichoptera [30,31]. The existence of theses taxa in water ecosystem indicates that the water quality was excellent [32].

The Shannon-wiener diversity index of macrozoobenthic found in all observed station ranges from $2.33-3.11$ (Table 2). Based on the index value, it is shown that the water was not polluted, as shown by $\mathrm{H}>2[33,34]$. This diversity index is one of the accurate index to examine level of pollution in water ecosystem caused by toxic materials [35]. The Family Biotic Index (FBI) value of macrozoobenthic shows level of pollution caused by organic matter. $\mathrm{FBI}$ value in all observed station ranges from $3.09-5.18$
(Table 2). Water quality in all station was grouped into three criteria, including very excellent, excellent and moderates [30]. All Subsay stations, $\mathrm{SP}_{3}$ middle stream and $\mathrm{SP}_{3}$ downstream stations grouped into sites with excellent water, all $\mathrm{SP}_{1}$ tations was excellent, while $\mathrm{SP}_{3}$ upstream station was moderates. It is caused by the high human activity in river, including recreation, bathing and washing. There also impact of agricultural activity with application of chemical fertilizer and pesticides surrounding $\mathrm{SP}_{3}$ stations [36]. Therefore, there are policy and attention needed to control and properly manage theses sites towards excellent water ecosystem quality.

Table 1. Spatial Distribution of Macrozoobenthic in the Study Sites

\begin{tabular}{|c|c|c|c|c|c|c|c|c|c|c|c|}
\hline \multirow{3}{*}{ Ordo } & \multirow{3}{*}{ Family } & \multirow{3}{*}{ Genus/Species } & \multicolumn{9}{|c|}{ Sampling Site } \\
\hline & & & \multicolumn{3}{|c|}{ Subsay } & \multicolumn{3}{|c|}{$\mathrm{SP}_{1}$} & \multicolumn{3}{|c|}{$\mathrm{SP}_{3}$} \\
\hline & & & Us & M & Ds & Us & $\mathbf{M}$ & Ds & Us & M & Ds \\
\hline Planaria & Planariidae & Planaria sp & + & & + & & & & & & \\
\hline \multirow[t]{6}{*}{ Coleoptera } & Hydrophilidae & Tropisternus sp & & & & + & & + & & & \\
\hline & Curculionidae & undertermined & & & + & & & & & & \\
\hline & Elmidae & undertermined & + & + & & & & & & & \\
\hline & Ptilodactylidae & undertermined & & & & & + & + & & & \\
\hline & Psephenidae & Ectopria sp & + & & & + & & & & & \\
\hline & Staphylinidae & undertermined & + & & & & & & & & \\
\hline \multirow[t]{5}{*}{ Diptera } & Ceratopogonidae & Ceratopogon sp & + & + & + & + & + & + & + & & \\
\hline & Chironomidae & Chironomus sp & & & & + & + & + & + & + & + \\
\hline & Simulidae & Simulium sp & + & + & + & & & + & + & + & + \\
\hline & Syrphidae & Eristalis sp & + & & & & & & & & \\
\hline & Tipulidae & Tipula sp & & & & + & & & & & + \\
\hline \multirow[t]{7}{*}{ Ephemeroptera } & Baetidae & Acentrella sp & & & & + & + & + & + & + & + \\
\hline & Baetidae & Baetis sp & + & + & + & + & + & + & + & + & + \\
\hline & Caenidae & Caenis sp & + & + & + & + & + & + & + & + & + \\
\hline & Ephemerellidae & Ephemerella sp & + & & & & & & & & \\
\hline & Heptageniidae & Epeorus sp & & & & & & & & + & \\
\hline & Pothaminthidae & Potamanthus sp & & + & + & & & & & & \\
\hline & Belastomatidae & Belastoma sp & + & + & & & & + & & & + \\
\hline \multirow[t]{6}{*}{ Odonata } & Chlorocyphidae & undertermined & + & + & & & & & & & \\
\hline & Corduliidae & Macromia sp & & + & & & & & & & \\
\hline & Gomphidae & undertermined & + & + & + & & & & + & + & \\
\hline & Libellulidae & Orthetrum sp & & & & + & + & + & & & + \\
\hline & Protoneuridae & undertermined & + & & + & & & & & & \\
\hline & Perlidae & undertermined & & & & & & & & & + \\
\hline Plecoptera & Glossosomatidae & undertermined & & & & & + & & & & \\
\hline \multirow[t]{6}{*}{ Tricophtera } & Hydropsychidae & Hydropsyche sp & + & + & + & + & + & + & + & + & + \\
\hline & Hydroptilidae & Tropilaelaps sp & & & & & + & & & & \\
\hline & Lepidostomatidae & Halesus sp & + & + & + & + & + & & + & + & + \\
\hline & Psychomyiidae & undertermined & & & & & + & & + & & \\
\hline & Rhyacophilidae & Rhyacophila sp & + & & & & + & & + & + & \\
\hline & Sericostomatidae & undertermined & & & & + & + & & & & \\
\hline
\end{tabular}

Notes: + = presence,Us = Upstream, $\mathrm{M}=$ Middle Stream, Ds = Downstream, $\mathrm{SP}_{1}=$ Prafi 1 River Reservoir, and $\mathrm{SP}_{3}=$ Prafi 3 River Reservoir. 
Table 2. The Water Quality of Prafi River based on Some Biotic Index of Macrozoobenthic

\begin{tabular}{|c|c|c|c|c|c|c|c|}
\hline Station & $\mathbf{H}^{\prime}$ & ASPT & TR & FBI & HBI & \% EPT & $\%$ Chi \\
\hline Subsay Upstream & $2.73 / \mathrm{E}$ & $7.00 / E$ & $6 / G$ & $3.09 / \mathrm{E}$ & 4.00/VG & 62.20 & 0 \\
\hline Subsay Middle stream & $2.84 / E$ & $7.13 / E$ & $4 / F$ & $3.75 / E$ & $4.54 / G$ & 73.15 & 0 \\
\hline Subsay Downstream & $2.68 / E$ & $7.00 / F$ & $5 / F$ & $3.66 / E$ & $4.40 / V G$ & 75.81 & 0 \\
\hline $\mathrm{SP}_{1}$ Upstream & $2.70 / E$ & $5.56 / G$ & $6 / G$ & $4.65 / G$ & $6.28 / \mathrm{F}$ & 65.00 & 25.00 \\
\hline $\mathrm{SP}_{1}$ Middle stream & 2.72/E & $6.00 / G$ & $10 / G$ & $4.46 / G$ & $5.74 / F$ & 74.79 & 18.49 \\
\hline $\mathrm{SP}_{1}$ Downstream & $2.60 / E$ & $5.00 / G$ & $4 / F$ & $4.91 / G$ & $6.53 / F P$ & 63.79 & 25.86 \\
\hline $\mathrm{SP}_{3}$ Upstream & $2.49 / E$ & $6.00 / G$ & $7 / G$ & $5.18 / F$ & $5.53 / F$ & 40.17 & 18.80 \\
\hline $\mathrm{SP}_{3}$ Middle stream & $3.11 / E$ & $6.86 / E$ & $7 / G$ & $3.56 / E$ & 4.09/VG & 80.20 & 4.99 \\
\hline $\mathrm{SP}_{3}$ Downstream & $2.33 / \mathrm{E}$ & $6.11 / E$ & $6 / G$ & $3.16 / \mathrm{E}$ & $3.91 / V G$ & 78.46 & 12.31 \\
\hline
\end{tabular}

Notes:

$\mathrm{SP}_{1}=$ Prafi 1 River Reservoir and $\mathrm{SP}_{3}=$ Prafi 3 River Reservoir. Water quality category: Excellent (E); Very Good (VG); Good (good); Fair (F); Fairly Poor (FP); $\mathrm{H}^{\prime}=$ Shannon- Wiener Diversity Index, ASPT= Average Score per Taxa, TR= Taxa Richness, FBI= Family Biotic Index, $\mathrm{HBI}=$ Hilsenhoff Biotic Index, EPT= Ephemeroptera Plecoptera and Trichoptera, Chi= Chironomidae [30-34, 37].

Effort to increase excellent water quality should be promoted, while regulation in the area which able to minimize water ecosystem threats should be well developed. Hilsenhoff Biotic Index (HBI) value of macrozoobenthic is the index that shows the level of pollution of water ecosystem by organic matter until species level. Result of the $\mathrm{HBI}$ value of all station ranges from 3.91 6.53 (Table 2). Water quality in all station was grouped into four criteria, i.e. very excellent, excellent, moderates and bad [30]. The Subsay upstream, Subsay downstream, $\mathrm{SP}_{3}$ middle stream and $\mathrm{SP}_{3}$ downstream station was classified into very excellent, while Subsay middle stream was excellent. $\mathrm{SP}_{1}$ upstream, $\mathrm{SP}_{1}$ middle stream and $\mathrm{SP}_{3}$ upstream stations were moderates, while $\mathrm{SP}_{1}$ downstream was bad. This is potentially occurs due to human visitation as tourist in water ecosystem and its recreation activity, especially in sites which area is accessible for tourist. In such area, there are waste produced by tourism activities. This result shows that water quality analysis with $\mathrm{HBI}$ consistent with result analysis based on $\mathrm{FBI}$ [30].

The Average Score per Taxa (ASPT) of macrozoobenthic is one of the index that able to show the water quality. The calculation of ASPT in all observed stations shows that the index range is 5.00-7.13 (Table 2). Water quality in all observed stations were grouped into two category; clean water (>6) and low polluted water (5-6) [30,37]. In Subsay, $\mathrm{SP}_{3}$ middle stream and $\mathrm{SP}_{3}$ downstream were grouped as freshwater. The water in $\mathrm{SP}_{3}$ upstream and all $\mathrm{SP}_{1}$ stations are low polluted. Human activity in observed stations area, including agriculture with chemical fertilizer and pesticides, stone and sand exploitation for construction material, and poor management of waste, high number of visitors, fishing and other recreational activities contributes to the pollution of the observed sites [36].
The Ephemeroptera Plecoptera and Trichoptera (EPT) value of macrozoobenthic based on the calculation of all observed station more than $50 \%$, except in station $\mathrm{SP}_{3}$ upstream (Table 2). The high value of EPT (more than 50\%) shows the excellent quality of water ecosystem [7]. The high value of EPT can be resulted from the abundance vegetation in riparian area of the river ecosystem. The nutrition to support macrozoobenthic lives in water ecosystem can be provided by vegetation in riparian ecosystem along the river $[30,31]$.

The EPT taxa richness (EPT richness) in all observed stations was given in Table 2 . There are 10 taxa in $\mathrm{SP}_{1}$ middle station, 7 taxa in $\mathrm{SP}_{3}$ upstream and $\mathrm{SP}_{3}$ middle stream, 6 taxa in Subsay upstream, $\mathrm{SP}_{1}$ upstream, and $\mathrm{SP}_{3}$ downstream stations, 5 taxa in Subsay downstream station, and 4 taxa Subsay middle stream and $\mathrm{SP}_{1}$ downstream stations. The taxa richness (EPT) ranges from 6-10, shows the water ecosystem is good (slight impact), while value of EPT richness between 2-5 is categorized as fair (moderate impact). Based on the EPT analysis, there are 6 locations with low pollution of organic materials, and 3 locations with organic pollution in medium level $[30,31,38]$.

\section{Water Quality Groups in Observation Sites based on Macrozoobenthic Biotic index and Principal Component Analysis}

Water quality in recreation sites area based on Macrozoobenthic biotic indices was classified into six category (Fig. 5). All Subsay stations were characterized by the high value of $\mathrm{H}^{\prime}$ and ASPT, taxa richness, moderate Chironomidae and low $\mathrm{HBI}$. The high value of $\mathrm{H}^{\prime}$ and ASPT shows absent of toxic compound in water environment, while the low $\mathrm{FBI}$ and moderate $\mathrm{HBI}$ shows less pollution by organic matter in normal level $[30,33,34]$. Based on the taxa richness, there is indication of organic matter pollution in low 
level. It can be said that this water has no pollution in observed water ecosystem or in an excellent quality [30].

The $\mathrm{SP}_{3}$ downstream station has high $\mathrm{H}^{\prime}$ and ASPT, with moderates taxa richness and Chironomidae. The high value of $\mathrm{H}^{\prime}$, ASPT and taxa richness was characterized by the absent of pollutant materials, especially anorganic or toxic materials, while the moderate value of Chironomidae shows relatively low organic pollutant $[6,30,33,34,39,40]$. It can be said that the water in observed station has been slightly polluted by organic matter. It is because there is small-scale agricultural activity with application of chemical fertilizer and pesticides surrounding the station [36].

The station of $\mathrm{SP}_{3}$ middle stream has high $\mathrm{H}^{\prime}$, ASPT and taxa richness, and low Chironomidae, $\mathrm{FBI}$ and $\mathrm{HBI}$. Based on these high value of $\mathrm{H}^{\prime}$, ASPT and taxa richness, this observed station can be said has no toxic pollutant and Chironomidae. The low value of $\mathrm{FBI}$ and $\mathrm{HBI}$ shows the low number of organic pollutant. Therefore, there has been pollution by organic pollutant in low level. It is caused by the high activity of human activity in river, including recreation, bathing and washing [36]. The Chironomidae is a pollutiontolerant taxa and the presence of these taxa may indicate moderate to poor water quality $[6,30,39,40]$.

The station $\mathrm{SP}_{1}$ middle stream has high $\mathrm{H}^{\prime}$ and taxa richness, moderates ASPT, and low value of
$\mathrm{FBI}$, Chironomidae and $\mathrm{HBI}$. Based on the high value of $\mathrm{H}^{\prime}$ and taxa richness in this station, it can be estimates that there are no pollution from toxic material [35]. The value of ASPT indicates slight pollution from anorganic compound. The low value of Chironomidae, $\mathrm{FBI}$ and $\mathrm{HBI}$ shows the low to moderate level of organic matter pollutant in water ecosystem [30]. These can be said that there are pollution in moderate level in observed station. It is caused by the high activity of human activity in river, including recreation, bathing and washing [36]. The Chironomidae is a pollution-tolerant taxa and the presence of these taxa may indicate moderate to poor water quality $[6,30,39,40]$.

Station of $\mathrm{SP}_{3}$ upstream has high value of $\mathrm{HBI}$, $\mathrm{FBI}$ and Chironomidae. The taxa richness was moderate while $\mathrm{H}^{\prime}$ and ASPT was low. Based on the high value of $\mathrm{HBI}, \mathrm{FBI}$ and Chironomidae with moderate value of taxa richness, this station can be identified with low to medium pollution caused by organic compound [30]. The low value of ASPT shows a slight pollution of anorganic matter. Therefore, it can be conclude that this station was polluted by organic compoud in medium level [30]. It is caused by the high numbers of human activity in river, including recreation, bathing and washing. There also impact of agricultural activity with application of chemical fertilizer and pesticides in the surrounding area of the station $[36,38]$.

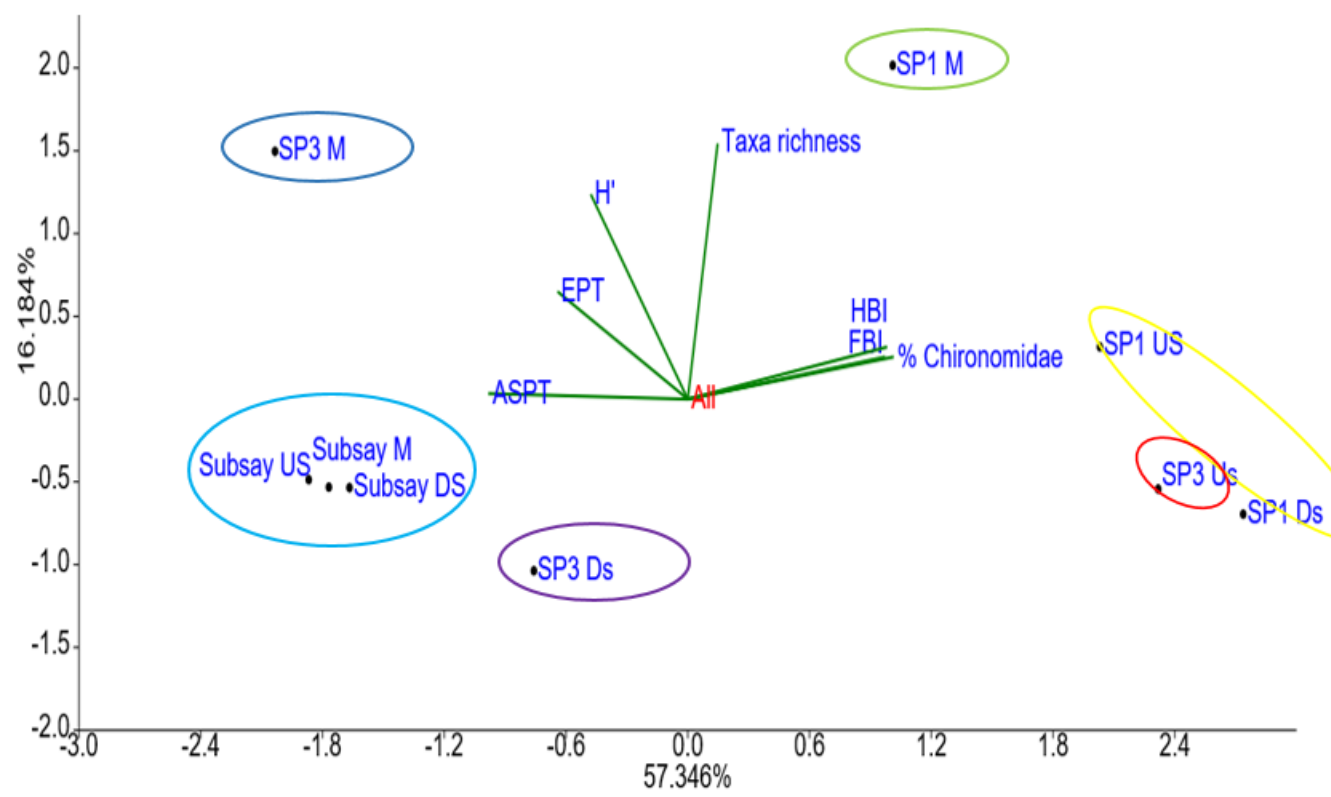

Figure 5. Principal Component Analysis (PCA) based on Macrozoobenthic Indices

Description: Us = Upstream, M = Middle Stream, Ds = Downstream, SP1 = Prafi 1 River Reservoir, and SP3 = Prafi 3 River Reservoir, $\mathrm{H}^{\prime}=$ Shannon- Wiener Diversity Index, ASPT= Average Score per Taxa, $\mathrm{FBI}=$ Family Biotic Index, $\mathrm{HBI}=$ Hilsenhoff Biotic Index, EPT= Ephemeroptera Plecoptera and Trichoptera. 
$\mathrm{SP}_{1}$ upstream and $\mathrm{SP}_{1}$ downstream stations has high $\mathrm{HBI}$ and Chironomidae value, medium taxa richness and $\mathrm{FBI}$ and low ASPT and $\mathrm{H}^{\prime}$. Based on these analysis, it can be said that these station has been moderately polluted by organic matter, while low ASPT shows the slight anorganic material pollution. From these data, it can be concluded that these stations polluted by organic matter in moderates level $[30,37]$. It is caused by the human activity in river, including recreation, bathing and washing [38]. There also impact of agricultural activity with application of chemical fertilizer and pesticides, mining of sand and stones, and the amount of garbage that still scattered from recreational activities [36]. Based on the Principal Component Analysis (PCA) from all stations, it can be said that all Subsay stations and $\mathrm{SP}_{3}$ downstream station has excellent quality. The $\mathrm{SP}_{3}$ middle stream and $\mathrm{SP}_{1}$ middle stream stations has moderate water quality. Otherwise, the $\mathrm{SP}_{3}$ upstream, $\mathrm{SP}_{1}$ upsteram and $\mathrm{SP}_{1}$ downstream stations has bad quality [14].

\section{CONCLUSION}

The physical and chemical characteristic of water in all observed stations according to PP. No. 82, 2001 was classified as class II, in which the water met to the activity for fisheries, recreation, animal husbandry and irrigation. The turbidity value of all stations are in range of maximum water turbidity standard of water environment according to WHO for drinking water ( $<5 \mathrm{NTU})$, except for all $\mathrm{SP}_{1}$ stations. The Prati's Index value of all station from the parameters of dissolve oxygen, BOD5, $\mathrm{pH}$, nitrate and orthophosphate shows that water quality was excellent to acceptable. Taxa richness of Macrozoobenthic in all observed station as calculated 31 individual from 7 class, including Platyhelminthes, Coleoptera, Diptera, Ephemeroptera, Odonata, Plecoptera and Trichoptera. Based on the some Macrozoobenthic biotic indices, it is clear that water in all Subsay stations and $\mathrm{SP}_{3}$ downstream station has excellent water quality. The $\mathrm{SP}_{3}$ middle stream and $\mathrm{SP}_{1}$ middle stream stations has moderates water quality, while in $\mathrm{SP}_{3}$ upstream, $\mathrm{SP}_{1}$ upstream and $\mathrm{SP}_{1}$ downstream was bad.

\section{ACKNOWLEDGEMENT}

We express our gratitude to the Ministry of Research and higher education in Indonesia and the postgraduate scholarship (BPPDN). We also thank to the University of Papua biology students who helped and accompanied in the field sampling. We also thank the Ecology Laboratory University of Brawijaya, Chemistry Laboratory and Biology Laboratory University of Papua, in facilitating the process of laboratory use, laboratory equipment and assistance form their analysts. Last, we thank all the biology students who have assisted in sampling.

\section{REFERENCES}

[1] Hall and Page. 1992. The geography of tourism and recreation: environmental, place and space. Routledge. New York.

[2] Salah, E. A. M., A. M. Turki and E. M. Othman. 2012. Assessment of water quality of Euphrates River using cluster analysis. Journal of Enviromental Protection 3, 16291633.

[3] Rosenberg, D. M. and V. H. Resh. 1993. Introduction to freshwater biomonitoring and benthic macroinvertebrates. In: Rosenberg, D.M. and V. H. Resh (Eds). Freswater biomonitoring and benthic macroinvertebrates. Chapman and Hall. New York.

[4] Sastrawijaya, A. T. 2000. Pencemaran lingkungan. Rineka cipta. Jakarta.

[5] Hakwes, H. A. 1979. Invertebrates as indicators of river water quality. In: James, A. and L. Evison (Eds). Biological Indicator of Water Quality. Academic Press. New York.

[6] Retnaningdyah, C. and E. Arisoesilaningsih. 2014. Evaluasi kualitas ekosistem mata air di Sumber Jenon, Awan, Mlaten, Umbul dan Guno berdasarkan parameter fisiko kimia dan makroinvertebrata bentos. Research Report on Grants of Higher Education to the Community. Department of Biology. Faculty of Mathematics and Natural Sciences. University of Brawijaya. Malang.

[7] Lestari, I. W. and Trihardiningrum. 2001. Bioassessment kualitas air Sungai Rejoso di Kecamatan Rejoso Pasuruan dengan makroinvertebrata. Bachelor Thesis. Department of Environmental Engineering. Faculty of Civil Engineering and Planning. Sepuluh Nopember Institute of Technology. Surabaya.

[8] Quigley, M. 1977. Invertebrates of streams and rivers: a key to identification. Edward Arnold Publ. Ltd. London.

[9] Clesceri, L. S., A. E. Greenberg and A. D. Eaton (Eds). 1999. Standard methods of examination of water and waste water, $18^{\text {th }}$ Ed. American Public Health Association, 
American Water Works Association, Water Environment Federation. Washington DC.

[10] Sen, F. and A. Aksoy. 2015. Chemicalphysical quality criteria of Bulakbasi Stream in Turkey and usage of drinking, fishery and irrigation. Journal of Chemistry, 20-25.

[11] Webster, R. and R.M., Lark. 2013. Field sampling for environmental science and management. Routledge Publisher.

[12] Jutting, W. S. S. and Van Bethem. 1953. Critical revision of the freshwater Javaneses Gastropod. Treubia. A Journal of Zoology, Hidrobiology and Oceanography of Indo Australians Archipelago 22(1), 259-477.

[13] Edmoson, W.T. 1963. Fresh water biology. John Wiley and Sons, Inc. New York.

[14] Kemple, W. G., P. M. Sadler and D. J. Strauss. 1989. A prototype constrained optimization solution to the time correlation problem. In: Agterberg, F. P. and G. F. Bonham-Carter (Eds). Statistical applications in the earth sciences. Geological Survey of Canada Paper 89(9), 417-425.

[15] Effendi, H. 2003. Telaah kualitas air. Kanisius. Yogyakarta.

[16] Government Regulation of Republic of Indonesia (PP RI). 2001. Pengelolaan kualitas air dan pengendalian pencemaran air. Ministry of Environment, Republic of Indonesia. Jakarta.

[17] Barus, T. A. 2001. Studi tentang ekosistem sungai dan danau. Faculty of Mathematics and Natural Sciences. University of North Sumatra. Medan.

[18] Firdaus, M. B., Irawan and N. Moehammadi. 2013. Keanekaragaman makroinvertebrata air pada vegetasi riparian Sungai Ordo Satu dan Sungai Ordo Dua di sistem Sungai Maron Desa Seloliman, Mojokerto. Jurnal IImiah Biologi 1, 51-60.

[19] Chua, T. E. 2010. A Preliminary on the plankton of the Ponggol Estuary. Hydrobio 35(13), 24-32.

[20] Habiebah, R. A. S. and C. Retnaningdyah. 2014. Evaluasi kualitas air akibat aktivitas manusia di mata air Sumber Awan dan salurannya, Singosari Malang. Jurnal Biotropika 2(1), 40-45.

[21] Abel, P. D. 1989. Water pollution biology. Ellis Horwood Limited Publisher. Chichester.

[22] World Health Organization (WHO). 2007. Chemical Safety of Drinking-water: assessing Priorities for Risk Management. WHO Press. Geneva, Switzerland.
[23] van de Meutter, F. 2005. Local and regional processes in macroinvertebrate communities in shallow lakes. Katholieke Universiteit Leuven, Faculteit Weteschappen Departement Biologie. Laboratorium voor Aquatische Ecologie. Belgium.

[24] Philminaq. 2014. Water quality and criteria and standarts for freshwater and marine aquaculture. PHILMINAQ: Mitigating Impact form Aquaculture in Philipines. Philiphine.

[25] Ferreira. 2008. Determining the influences of Land use patterns on the diatom, macroinvertebrata and riparian vegetation integrity of the lower Harts/Vaal river systems. Dissertation. University of Johannesburg.

[26] Ott, W. R. 1978. Enviromental indices theory and pratice. Annrbor Scin. Publ. Inc. Ann Arbor. Mich. Wasington, DC.

[27] Nordhaus, I. T. Salewski and T. C. Jennerjahn. 2011. Food preferences of mangrove crabs related to leaf nitrogen compounds in the Segara Anakan Lagoon, Java, Indonesia. Journal of Sea Research 65(4), 414-426.

[28] Hsieh, H. L., C. P. Chen, Y. G. Chen and H. H. Yang. 2002. Diversity of benthic organic matter flows through polychaetes and crabs in a mangrove estuary: $\delta 13 \mathrm{C}$ and 834S signals. Marine Ecology Progress Series 227, 145-155.

[29] Bouillon, S., T. Moens, I. Overmeer, N. Koedam and F. Dehairs. 2004. Resource utilization patterns of epifauna from mangrove forests with contrasting inputs of local versus imported organic matter. Marine Ecology Progress Series 278, 77-88.

[30] Mandaville, S. M. 2002. Benthic Macroinvertebrata in freshwater-taxa tolerance values, metric and protocols. Soil and Water Conservation Society of Metro. Halifax.

[31] Miserendino, M. L. and L. A. Pizzolon. 2001. Abundance and altitudinal distribution of Ephemeroptera in an Andean-Patagonean River system (Argentina). In: Dominguez, E. (Ed). Trends in research in Ephemeroptera and Plecoptera. Kluwer Academic. The Netherlands. 135-142.

[32] Rini, D. A. 2007. Mengenal makroinvertebrata bentos. Warta Konservasi Lahan Basah. Available at: http://papua web.org/dlib/jr/wklb/edisiokt2007.pdf.

[33] Lee, C. D., S. B. Wang and C. L. Kuo. 1978. Benthic macroinvertebrate and fish as 
biological indicator of water quality: with reference on water pollution control in developing countries. Bulletin of C. Sciences Bangkok.

[34] Krebs, C. J. 1989. Experimental analysis of distribution and abudance, $3^{\text {rd }} \mathrm{Ed}$. Harper and Row Publisher. New York.

[35] El Sherief, M. Z., A. M. Gharib, A. J. AbdelHalim and A. A. Radwan. 2011. Phytoplankton and environmental variables as a water quality indicator for the beaches at Matrouh, Sout- Eastern, Mediterranian Sea, Egypt: assessment. Oceanologia 53(7), 98109.

[36] Meybeck, M. 2003. Global analysis of river systems: from Earth system controls to Anthropocene syndromes. Philosophical Transactions of the Royal Society of London B1379, 1-21.

[37] Armitage, P. D., D. Moss, J. F. Wright and M. T. Furse. 1983. The performance of anew biological water quality score system based on macroinvertebrates over a wide range of unpolluted running-water sites. Water Research 17, 333-347.

[38] Carpenter, R., N. F. Caraco, D. L. Corre, R. W. Howarth, A. N. Sharpley and V. H. Smith. 1998. Non point pollution of surface water with phosphorus and nitrogen. Ecologic Application 8(3), 555-568.

[39] Wallace, J. B. and J. R. Webster. 1996. The role of macroinvertebrates in stream ecosystem function. Annual Review of Entomology 41, 115-139.

[40] Badawy, R. M., E. I. Hoseny and M. Talal. 2013. Biodiversity and seasonal fluctuation of aquatic and semiaquatic insects in Rashid Stream, Kafr El Zayat. Egyptian Academic Journal of Biological Sciences 6(1), 47-66. 